九州大学学術情報リポジトリ

Kyushu University Institutional Repository

Binding of phospholipase C-related but catalytically inactive protein to phosphatidylinositol 4,5-bisphosphate via the $\mathrm{PH}$ domain

高, 靖

九州大学大学院歯学府口腔常態制御学講座口腔細胞工学分野

https://doi.org/10.15017/18383

出版情報：九州大学，2009，博士（歯学），課程博士 バージョン：

権利関係 : 


\title{
Binding of phospholipase C-related but catalytically inactive protein to phosphatidylinositol 4,5-bisphosphate via the $\mathrm{PH}$ domain
}

\author{
Jing Gao, Hiroshi Takeuchi, Zhao Zhang, Makoto Fujii, Takashi Kanematsu, Masato Hirata* \\ Laboratory of Molecular and Cellular Biochemistry, Faculty of Dental Science, Kyushu University, Fukuoka 812-8582, Japan
}

\section{A R T I C L E I N F O}

\section{Article history:}

Received 20 February 2009

Accepted 9 March 2009

Available online 17 March 2009

\section{Keywords}

Calcium

Inositol trisphosphate

Phosphoinositide

Phospholipase C

Pleckstrin homology domain

\begin{abstract}
A B S T R A C T
A well-known protein module regulating molecular interactions is the pleckstrin homology $(\mathrm{PH})$ domain whose best-characterised ligand is phosphoinositide. In the present study, we analysed the PH domain from PRIP (phospholipase C-related but catalytically inactive protein, comprising types 1 and 2) regarding phosphatidylinositol 4,5-bisphosphate [PtdIns $(4,5) \mathrm{P}_{2}$ ] binding employing a variety of binding assays. The $\mathrm{PH}$ domains prepared from PRIP-1 and -2 showed similar binding profiles to soluble ligands in vitro and showed similar plasma membrane localisation to that of PLC- $\delta 1$; however, the PH domain with the N-terminal extension of PRIP-1 but not PRIP-2 showed even distribution throughout the cytoplasm, indicating that the $\mathrm{N}$-terminal extension of PRIP-1 inhibited binding to PtdIns $(4,5) \mathrm{P}_{2}$ present in the plasma membrane. A chimeric molecule of PLC- $\delta 1$ PH domain with the N-terminal extension of PRIP-1 exhibited similar localisation to PRIP-1 PH domain with the N-terminal extension. Binding assay to liposomes containing various concentrations of $\operatorname{PtdIns}(4,5) \mathrm{P}_{2}$ revealed that the PH domain of PLC- $\delta 1$ bound steeply to the maximum, even at a concentration of $1.2 \mathrm{~mol} \%$, whereas the PH domains from PRIP-1 and -2 bound depending on the concentration up to $5 \mathrm{~mol} \%$. We also performed binding experiments using saponinpermeabilised PC12 cells. PH domains from PRIP increased the binding to cells preincubated with the brain cytosol extract in the presence of ATP, during which PtdIns $(4,5) \mathrm{P}_{2}$ were probably synthesised. The binding of $\mathrm{PH}$ domain with the following EF hand motifs showed $\mathrm{Ca}^{2+}$-dependent binding. These results indicate that the $\mathrm{PH}$ domain of PRIP binds to $\operatorname{PtdIns}(4,5) \mathrm{P}_{2}$ present in the plasma membrane, depending on the concentrations of the lipid ligand and $\mathrm{Ca}^{2+}$, suggesting that PRIP might play physiological roles in events involved in the changes of these parameters, probably including $\operatorname{Ins}(1,4,5) \mathrm{P}_{3}$.
\end{abstract}

(c) 2009 Elsevier Inc. All rights reserved.

\section{Introduction}

Phospholipase C-related, but catalytically inactive protein (PRIP-1) was first identified in the brain cytosol fraction as a novel D-myoinositol 1,4,5-trisphosphate [ $\left.\operatorname{Ins}(1,4,5) \mathrm{P}_{3}\right]$ binding protein and was tentatively named p130 based on molecular size [1]. Subsequent molecular cloning studies revealed that the molecule is similar to phospholipase C- $\delta 1$ but catalytically inactive, which is the reason for the revised name [2-5]. In an attempt to explore the biological function of PRIP-1 in relation to the binding to $\operatorname{Ins}(1,4,5) \mathrm{P}_{3}$ via its pleckstrin homology $(\mathrm{PH})$ domain [6,7], we performed serial experiments, first using COS-1 cells stably over-expressing PRIP-1 [8] and then cultured neurons prepared from PRIP-1 knock-out mice [9]. The results showed that both cells over-expressing and little-expressing PRIP-1 produced a reduced Ins $(1,4,5) \mathrm{P}_{3}$-mediated $\mathrm{Ca}^{2+}$ increase in cells, probably for different reasons $[8,9]$, indicating that the presence

\footnotetext{
* Corresponding author. Tel.: +8192642 6317; fax: +81926426322. E-mail address: hirata1@dent.kyushu-u.ac.jp (M. Hirata).
}

of an appropriate amount of PRIP-1 is needed to produce right Ins $(1,4,5) \mathrm{P}_{3}$-mediated $\mathrm{Ca}^{2+}$ signalling.

PRIP-1 was also isolated from the membrane fraction of the brain with much the same molecular size as that from the cytosol fraction [5], indicating no lipid modification for localisation in the membrane fraction, but association to the membrane constituents. The most feasible constituent of molecules bearing $\mathrm{PH}$ domains would be phosphatidylinositol 4,5-bisphosphate [PtdIns $(4,5) \mathrm{P}_{2}$ ], which is a minor but key phospholipid mainly on the cytoplasmic leaflet of the plasma membrane. We then performed cellular experiments using COS-1 cells transfected with genes for a variety of deletion mutants of PRIP-1 to examine whether the PH domain is implicated in membrane localisation by binding to $\operatorname{PtdIns}(4,5) \mathrm{P}_{2}$, and drew the tentative conclusion that the membrane association of PRIP-1 indeed occurred, but the association via the binding of the $\mathrm{PH}$ domain to $\operatorname{PtdIns}(4,5) \mathrm{P}_{2}$ was partial [10]. Subsequently, in vitro experiments using the liposomes containing PtdIns $(4,5) \mathrm{P}_{2}$ clearly indicated that the $\mathrm{PH}$ domain of PRIP- 1 binds PtdIns $(4,5) \mathrm{P}_{2}$, and further $\mathrm{Ca}^{2+}$ at physiological concentration enhances the binding when the recombinant $\mathrm{PH}$ domain molecule used contains EF hand motifs, like those of PLC- $\delta$ [11,12]. 
We also observed that full-length PRIP-1 was mainly localised in the cytoplasm $[6,8]$, but the isolated PH domain (amino acid residues $82-298$ ) was mainly seen at the surface membrane $[8,13]$. We further examined the recombinant molecule comprising N-terminal extension (residues 24-81) plus the $\mathrm{PH}$ domain regarding localisation, resulting in the main location in the cytoplasm. These results indicate that the N-terminal region of PRIP-1 preceding the PH domain would prohibit it from associating with the surface membrane. Furthermore, an isoform of PRIP-1 with relatively broad tissue distribution, including the brain, was also reported [14,15], indicating that PRIP comprises types 1 and 2 .

PtdIns $(4,5) \mathrm{P}_{2}$ has been receiving constant attention because it regulates a wide variety of processes, including exocytic and endocytic membrane traffic [16-20], ion channel and transporter function [21], enzyme activation [22], and protein recruitment [23-26]. In order to extend our researches in exploring the biological function of PRIP, probably through competing for PtdIns $(4,5) \mathrm{P}_{2}$ with other molecules involved in the functions described above, it would be important to reevaluate whether the $\mathrm{PH}$ domain is involved in the membrane association of PRIP via binding to PtdIns $(4,5) \mathrm{P}_{2}$.

In the present study, we examined the cellular localisation and binding to PtdIns $(4,5) \mathrm{P}_{2}$-containing liposome of the $\mathrm{PH}$ domains derived from PRIP-2 as well as PRIP-1, and further evaluated the effect of N-terminal extension on the localisation of the PH domain. Finally, we examined whether the association is indeed regulated by PtdIns $(4,5) \mathrm{P}_{2}$ via binding by the $\mathrm{PH}$ domain, employing semi-intact cellular experiments.

\section{Materials and methods}

\subsection{Materials}

$\left[{ }^{3} \mathrm{H}\right] \operatorname{Ins}(1,4,5) \mathrm{P}_{3}$ (specific radioactivity: $851.0 \mathrm{GBq} / \mathrm{mmol}$ ) was purchased from PerkinElmer (Waltham, MA). Ins $(1,4,5) \mathrm{P}_{3}$ and shortchain (C8, water-soluble) PtdIns $(4,5) \mathrm{P}_{2}$ and natural PtdIns $(4,5) \mathrm{P}_{2}$ were obtained from Cell Signal Inc. (Lexington, KY). Glutathione-Sepharose 4B and pGEX vectors were from GE Healthcare (Uppsala, Sweden). pEGFP-N1 vector was from Clontech (Palo Alto, CA). Phosphatidylcholine (PC) was purchased from Sigma (St. Louis, MO). Monoclonal antibody against GST was from Santa Cruz Biotechnology (Santa Cruz, CA). Other reagents used were of the highest grade available.

\subsection{DNA constructs, recombinant protein expression and purification}

The PH domain of human PLC- $\delta 1$ (residues 1-140), and its mutant R40L was described previously [27,28]. The long version of PH domain (1-298) of PRIP-1 (1PHL) was amplified from full-length PRIP-1 construct using the primers 5'-TAGAATTCCACCATGGCTGAGGGCGCGG$3^{\prime}$ and 5'-ATGTCGACCGGGTAGTTAGTTTTTCTTTGC-3'. The short version (1PHS, 74-298) was amplified using the primers 5'-TAGAATTCCACCATGCCCCGGCGCACGAGCATC-3' and 5'-ATGTCGACCGGGTAGTTAGTTTTTCTTTGC-3'. The long version of the PH domain (1-325) of PRIP-2 (2PHL) was amplified from full-length PRIP-2 using the primers 5'-TAGAATTCCACCATGGCGGAGTGCGGCC-3' and 5'-ATGTCGACTCGGTACCAGCTTTGTCCTTTG-3'. The short version (2PHS, 102-325) was amplified using the primers 5'-TAGAATTCCACCATGCCCCGCCGGAGCAGCATC-3' and 5'-ATGTCGACTCGGTACCAGCTTTGTCCTTTG-3'. After the digestion with EcoRI and SalI, the product was ligated into the pEGFP-N1 plasmid (CLONTECH) and pGEX-4T3 plasmid digested with the same enzymes. The chimeric molecule of the PLC- $\delta 1-\mathrm{PH}$ domain $(1 \mathrm{~N}-\delta \mathrm{PH})$ was created by connecting the N-terminal PRIP-1 (1-81 residues) with PLC- $\delta 1 \mathrm{PH}$ (1-142 residues). The mutant form of 1PHS (1PHSm) was also generated in plasmids pGEX-4T3 and pEGFP-N1 by site-directed mutagenesis (Quick Change; Stratagene) using the primers $5^{\prime}$-CTCTCGCATCTACAACCAATTTTTCACCCTAGACAC-3' and 5'-GTGTCTAGGGTGAAAAATTGGTTGTAGATGCGAGAG-3' for R134Q.
For purification of recombinant PH domains conjugated with GST, Escherichia coli BL-21(DE3) was transformed with pGEX-4T3 constructs. The bacterial cells were grown up to 0.4 of absorbance at $600 \mathrm{~nm}$ at $37{ }^{\circ} \mathrm{C}$ and then with $250 \mu \mathrm{M}$ isopropyl $-\beta-\mathrm{D}(-)-$ thiogalactopyranoside (IPTG) at $18-20{ }^{\circ} \mathrm{C}$ for an additional $12-14 \mathrm{~h}$. Bacterial lysate was prepared by sonication in a lysis buffer [50 mM Tris- $\mathrm{HCl}$ (pH 8.0), $300 \mathrm{mM} \mathrm{NaCl}, 1 \mathrm{mM}$ EDTA, 1 mM DTT and protease inhibitor cocktail containing $5 \mu \mathrm{g} / \mathrm{ml}$ pepstatin $\mathrm{A}, 10 \mu \mathrm{M}$ leupeptin, $1.7 \mu \mathrm{g} / \mathrm{ml}$ aprotinin, and $50 \mu \mathrm{M}$ 4-amidinophenylmethanesulfonyl fluoride hydrochloride], followed by rotation after the addition of $1 \%$ Triton X-100 for 20 min. Purification was achieved using GlutathioneSepharose $4 \mathrm{~B}$ beads. After extensive washing with a lysis buffer without protease inhibitor cocktail, the proteins were eluted with $20 \mathrm{mM}$ reduced glutathione in a lysis buffer without protease inhibitor cocktail, but containing $1 \mathrm{mM}$ DTT. Purity was checked by staining with Coomassie Brilliant Blue (CBB) in SDS-polyacrylamide gel electrophoresis (SDS-PAGE). The recombinant molecules of interest were dialyzed against the solution for assay for more than $6 \mathrm{~h}$, followed by centrifugation at 100,000 $\mathrm{g}$ for $30 \mathrm{~min}$ before use.

\subsection{Binding assay of recombinant proteins to $\left[{ }^{3} \mathrm{H}\right] \mathrm{Ins}(1,4,5) \mathrm{P}_{3}$}

The binding to $\left[{ }^{3} \mathrm{H}\right] \operatorname{Ins}(1,4,5) \mathrm{P}_{3}(0.9 \mathrm{nM} ; 0.37 \mathrm{kBq}$ radioactivity) of each recombinant protein $(8 \mathrm{pmol})$ was performed in a reaction mixture $(0.45 \mathrm{ml})$ containing $50 \mathrm{mM}$ Tris- $\mathrm{HCl}$ ( $\mathrm{pH} 8.3), 0.2 \%$ Triton X100 , and $2 \mathrm{mM}$ EGTA. The reaction mixture was incubated on ice for $15 \mathrm{~min}$, followed by the addition of $50 \mu \mathrm{l}$ of $10 \mathrm{mg} / \mathrm{ml}$ bovine gglobulin and $0.5 \mathrm{ml}$ of $30 \%(\mathrm{w} / \mathrm{v})$ polyethyleneglycol 6000 . The precipitate formed after centrifugation at $15,000 \mathrm{rpm}$ for 5 min was dissolved in $0.5 \mathrm{ml}$ of $0.1 \mathrm{~N} \mathrm{NaOH}$ and then counted for radioactivity as an emulsion with $5 \mathrm{ml}$ scintillation cocktail. Non-specific binding in the presence of $100 \mu \mathrm{M}$ unlabelled Ins $(1,4,5) \mathrm{P}_{3}$ was also measured (approximately 200-250 dpm) and subtracted from the values measured in its absence (range 3500-5800 dpm), enabling calculation of the specific binding.

\subsection{Binding assay of recombinant proteins to liposomes}

Liposomes composed of phosphatidylcholine (PC) or with PtdIns $(4,5) \mathrm{P}_{2}$ were made according to the method described [29]. Briefly, PC alone or with PtdIns $(4,5) \mathrm{P}_{2}$ at different concentrations dissolved in chloroform solution was dried under nitrogen to make a lipid film in a glass tube. A solution (buffer A) containing $25 \mathrm{mM}$ Hepes/ $\mathrm{NaOH}$ buffer ( $\mathrm{pH} 7.4$ ), $100 \mathrm{mM} \mathrm{NaCl}$ and $1 \mathrm{mM}$ DTT was added to make a final lipid concentration of $20 \mathrm{mM}$ and the mixture was sonicated twice until uniform turbidity was achieved so that small unilamellar vesicles were formed. Stock liposomes thus made were kept in a refrigerator until use (for approximately a month). The phospholipid vesicles (final conc. of total lipid was $1 \mathrm{mM}$ ) were mixed with purified recombinant proteins in $50 \mu \mathrm{l}$ buffer B [20 mM Tris- $\mathrm{HCl}$ ( $\mathrm{pH} 7.5$ ), $150 \mathrm{mM} \mathrm{NaCl}, 1 \mathrm{mM}$ EDTA and $1 \mathrm{mM}$ DTT]. The mixture was incubated on ice for $10 \mathrm{~min}$, followed by centrifugation at $100,000 \mathrm{~g}$ for $30 \mathrm{~min}$. The supernatant was carefully removed, and mixed with $5 \times$ concentrated sample buffer for SDS-PAGE to a final volume of $50 \mu \mathrm{l}$. The pellet was dissolved in SDS buffer up to the same volume ( $50 \mu \mathrm{l})$. Both the supernatant and the pellet were analysed by SDS-PAGE, followed by staining with CBB. Densitometric analyses were performed on the stained gel with an NIH image analyser. Bovine serum albumin was used as the standard protein to assess the linearity of protein concentration after staining with "Quick CBB" (Wako Pure Chemical Co. Ltd., Tokyo, Japan) for $30 \mathrm{~min}$.

\subsection{Binding assay of recombinant proteins to permeabilised PC12 cells}

The binding assay of recombinant proteins to permeabilised PC12 cells was performed as described [30]. PC12 cells were permeabilised 
using $0.05 \%$ saponin on ice for $15 \mathrm{~min}$, followed by vigorous washing with KGlu buffer [20 mM Hepes/KOH (pH 7.2), $120 \mathrm{mM}$ potassium glutamate, $20 \mathrm{mM}$ potassium acetate, $2 \mathrm{mM}$ EGTA]. Cells suspended in a KGlu buffer (in the absence of Mg-ATP) were left at room temperature for $20 \mathrm{~min}$ for consistent results. Permeabilised PC12 cells were then incubated with rat brain extract $(0.5 \mathrm{mg} / \mathrm{ml})$ prepared as described [31] in the presence of Mg-ATP at $30{ }^{\circ} \mathrm{C}$ for $10 \mathrm{~min}$, and then washed once briefly. The cells $\left(8 \times 10^{5}\right.$ cells $)$ were incubated with the recombinant molecule (GST-conjugated) of interest for $30 \mathrm{~min}$ on ice in a total volume of $200 \mu$, followed by separation of the mixture by rapid centrifugation (30 s, 21,600 g) through $0.0625 \%$ sucrose in KGlu buffer $(200 \mu \mathrm{l})$. Supernatants were carefully withdrawn, tubes were wiped carefully, and cell pellets were resuspended in SDS sample buffer, followed by separation by SDS-GAGE, transfer to a polyvinylidene fluoride membrane and analysis by Western blotting using anti-GST antibody for the experiments and anti- $\beta$-actin antibody as a reference.

\subsection{Transfection of cells for confocal microscopy}

Madin-Darby canine kidney (MDCK) cells were plated onto 14mm diameter circular glass coverslips at a density of $4 \times 10^{4}$ cells/well in a 12-well plate and cultured in Dulbecco's modified Eagle's medium with $10 \%(\mathrm{v} / \mathrm{v})$ fetal bovine serum for a day. The cells were then transiently transfected with plasmid DNAs $(1 \mu \mathrm{g})$ using Lipofectamine2000 and OPTI-MEM (Invitrogen) according to the manufacturer's protocol. Twenty-four hours after transfection, the cells were fixed with $4 \%$ paraformaldehyde and observed by a confocal laser scanning microscope (Zeiss: LSM510-Meta).

\section{Results and discussion}

\subsection{Constructs prepared from PRIP-1 and -2 , and their cellular localisation}

Fig. $1 \mathrm{~A}$ is a schematic representation of the constructs used in the present study. A long version of the PH domain from PRIP-1 (amino acid residue 1-298, abbreviated as $1 \mathrm{PHL}$ ) and -2 (amino acid residue $1-325,2 \mathrm{PHL}$ ) contained the $\mathrm{N}$-terminal extension preceding the $\mathrm{PH}$ domain, while the short version (amino acid residues 74-298 and 102-325 for 1 PHS and 2PHS, respectively) lacked it. The PH domain of PLC- $\delta 1(\delta \mathrm{PH}$, amino acid residue $1-142)$ was employed as a reference since it is well recognised to localise at the surface membrane by direct binding to PtdIns $(4,5) \mathrm{P}_{2}$ [27,32-34]. In this case, to test whether the N-terminal extension preceding the PH domain seen in the PRIP family can influence the localisation of the PH domain, a chimera was also constructed incorporating the N-terminal extension from PRIP-1 $(1 \mathrm{~N}-\delta \mathrm{PH})$. All constructs were conjugated with EGFP (enhanced green fluorescent protein) for mammalian cells or GST (glutathione $S$ transferase) for the E. coli expression system at the C-terminus for visualisation or binding assay, respectively. Fig. $1 \mathrm{~B}$ shows the $\mathrm{CBB}$ staining pattern of purified samples, indicating that major positive bands were seen at the molecular sizes expected. The gel also contained the mutant of 1 PHS in which R134 was mutated to Q (1PHSm), which corresponds to critical R40 in PLC-81 [27,34]. Fig. 1C depicts the domain organisation of PRIP and PLC- $\delta 1$ for references.

We first examined the binding properties of these molecules isolated by the E. coli expression system to $\operatorname{Ins}(1,4,5) \mathrm{P}_{3}$ and PtdIns $(4,5) \mathrm{P}_{2}$ in a solution. Each molecule examined, except for $1 \mathrm{PHSm}$, exhibited binding ability to $\left[{ }^{3} \mathrm{H}\right] \mathrm{Ins}(1,4,5) \mathrm{P}_{3}$ which was displaced by unlabelled Ins $(1,4,5) \mathrm{P}_{3}$ and water-soluble (short-chain, C8)-PtdIns $(4,5) \mathrm{P}_{2}$ in a dose-dependent manner (Fig. 2). The values of $I C_{50}$ indicate the gross binding affinity; those of Ins $(1,4,5) \mathrm{P}_{3}$ and PtdIns $(4,5) \mathrm{P}_{2}$ were as follows in nM: $1 \mathrm{PHS}$ ( 40 and 110$), 1 \mathrm{PHL}$ (30 and 90) or 2PHS (40 and 130) and 2PHL (30 and 90), respectively. Collectively, the affinity to Ins $(1,4,5) \mathrm{P}_{3}$ appeared to be about 3-fold higher than to PtdIns $(4,5) \mathrm{P}_{2}$, but there was little difference between short and long versions, and between types 1 and 2 .

MDCK cells were transfected with expression plasmids to examine the cellular localisation of these PH domains. As shown in Fig. 3, molecules 1PHS, 2PHS and 2PHL fused with GFP were mainly found close to the surface membrane, the pattern of which is similar to that
A

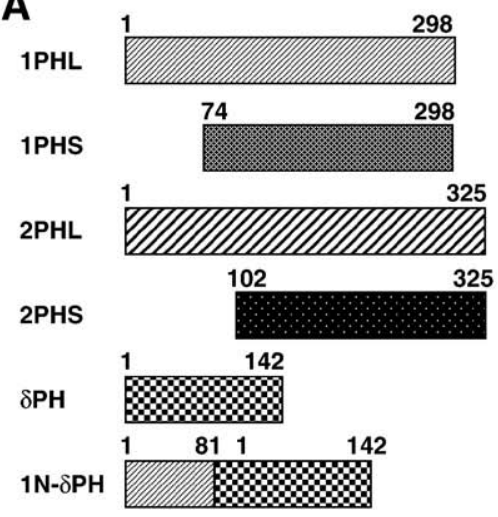

C
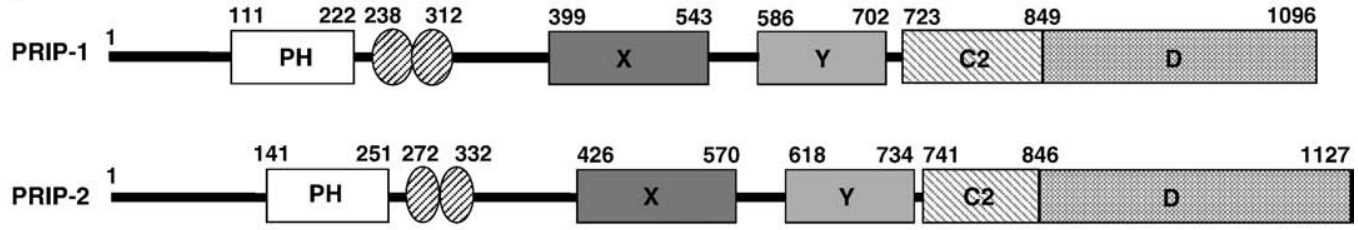

PLC- $\delta 1$

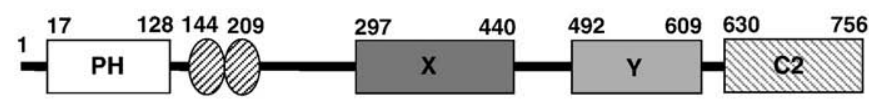

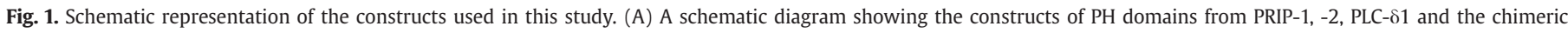

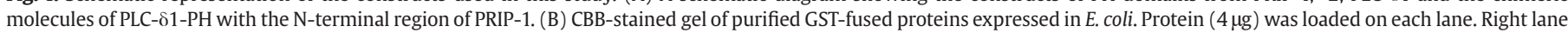
represents molecular weight markers. (C) Domain organisation of PRIP-1, -2 and PLC- $\delta 1$. Numbers indicate the starting and ending amino acid of each domain. 
A
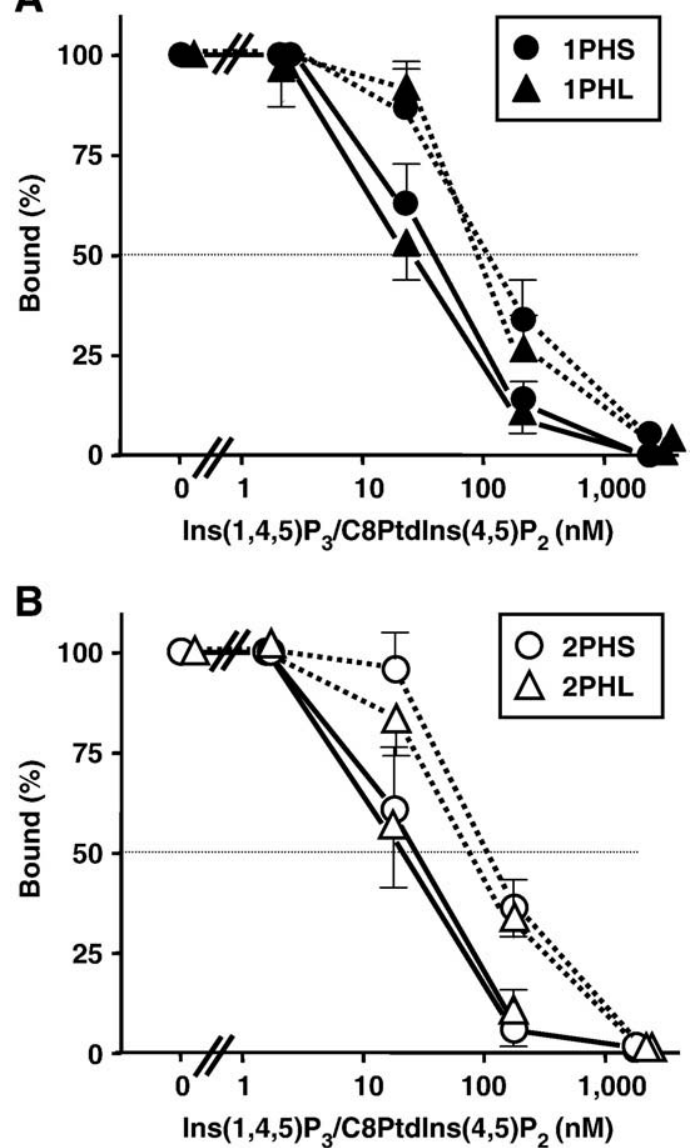

Fig. 2. Binding of $\mathrm{PH}$ domains to $\left[{ }^{3} \mathrm{H}\right] \mathrm{Ins}(1,4,5) \mathrm{P}_{3}$ and the displacement by $\operatorname{Ins}(1,4,5) \mathrm{P}_{3}$ and PtdIns $(4,5) \mathrm{P}_{2}$. $\left[{ }^{3} \mathrm{H}\right] \operatorname{Ins}(1,4,5) \mathrm{P}_{3}$ bound to $\mathrm{PH}$ domain was displaced by various concentrations of unlabelled Ins $(1,4,5) \mathrm{P}_{3}$ (solid lines) or C8 (water-soluble) PtdIns $(4,5)$ $\mathrm{P}_{2}$ (dotted lines). All recombinant molecules assayed ((A) 1PHS, 1PHL and (B) 2PHS, 2PHL, see Fig. 1A) were conjugated with GST for purification [see Fig. 1B for purity]. Thin dotted line indicates $50 \%$ displacement. Results are shown as the mean $\pm \mathrm{SE}$ of four independent experiments.

observed with $\delta \mathrm{PH}$, whereas molecule $1 \mathrm{PHL}$ were mainly found in the cytoplasm. 1PHSm also showed a similar pattern to $1 \mathrm{PHL}$ (results not shown). A distinct difference between the long and short versions was thus observed with the PH domain of PRIP-1. These observations indicate that the binding affinities of these $\mathrm{PH}$ domains assessed by displacement of bound $\left[{ }^{3} \mathrm{H}\right] \operatorname{Ins}(1,4,5) \mathrm{P}_{3}$ by $\operatorname{Ins}(1,4,5) \mathrm{P}_{3}$ and PtdIns $(4,5) \mathrm{P}_{2}$ in a solution do not necessarily explain the difference in cellular localisation.

The N-terminal region composed of residues 1-73 from PRIP-1, but not the corresponding region (residue 1-101) of PRIP-2, seems to cause the difference by prohibiting the $\mathrm{PH}$ domain (74-298) from coming close to the surface membrane. To examine whether this is applicable to $\delta \mathrm{PH}$, which binds both $\operatorname{PtdIns}(4,5) \mathrm{P}_{2}$ and $\operatorname{Ins}(1,4,5) \mathrm{P}_{3}$ with similar affinity (see Fig. 4B) [1,6,27], the chimera abbreviated as $1 \mathrm{~N}-\delta \mathrm{PH}$ in Fig. $1 \mathrm{~A}$ was expressed in MDCK cells. As shown in Fig. $4 \mathrm{~A}$, cytoplasmic fluorescence in a diffuse fashion appeared to be increased by incorporating the N-terminal extension of PRIP-1. This does not appear to be caused by changes in binding properties to the ligands in a solution; the displacement profile of bound $\left[{ }^{3} \mathrm{H}\right] \operatorname{Ins}(1,4,5) \mathrm{P}_{3}$ by Ins $(1,4,5) \mathrm{P}_{3}$ and short-chain (C8)-PtdIns $(4,5) \mathrm{P}_{2}$ was not different between $\delta \mathrm{PH}$ and $1 \mathrm{~N}-\delta \mathrm{PH}$ (Fig. $4 \mathrm{~B}$ ), indicating that $\mathrm{N}$-terminal extension does not influence the binding profile to soluble ligands, but might provide sterical hindrance or physically interact with other molecules inside cells, thus leading to the inhibition of $\mathrm{\delta PH}$ to bind PtdIns $(4,5) \mathrm{P}_{2}$ present in the surface membrane. Similar results were observed when a chimera abbreviated as 1N-2PHS (N-terminal extension of PRIP-1 connected to type 2 PH short version) was used (results not shown).

The appearance of the isolated $\mathrm{PH}$ domain in intact cells represented by $1 \mathrm{PHS}$ and $2 \mathrm{PHL}$, shown in Fig. 3, seemed to be attributed to the direct association with $\operatorname{PtdIns}(4,5) \mathrm{P}_{2}$ present at the inner leaflet of the surface membrane because 1 PHSm exhibited cytoplasmic localisation, and the binding to reconstituted liposomes containing PtdIns $(4,5) \mathrm{P}_{2}$ increased as the concentration increased, as shown in Fig. 5. These observations were similar to those observed with $\delta \mathrm{PH}$, but the affinity of $\delta \mathrm{PH}$ to PtdIns $(4,5) \mathrm{P}_{2}$ present in liposomes appeared

A
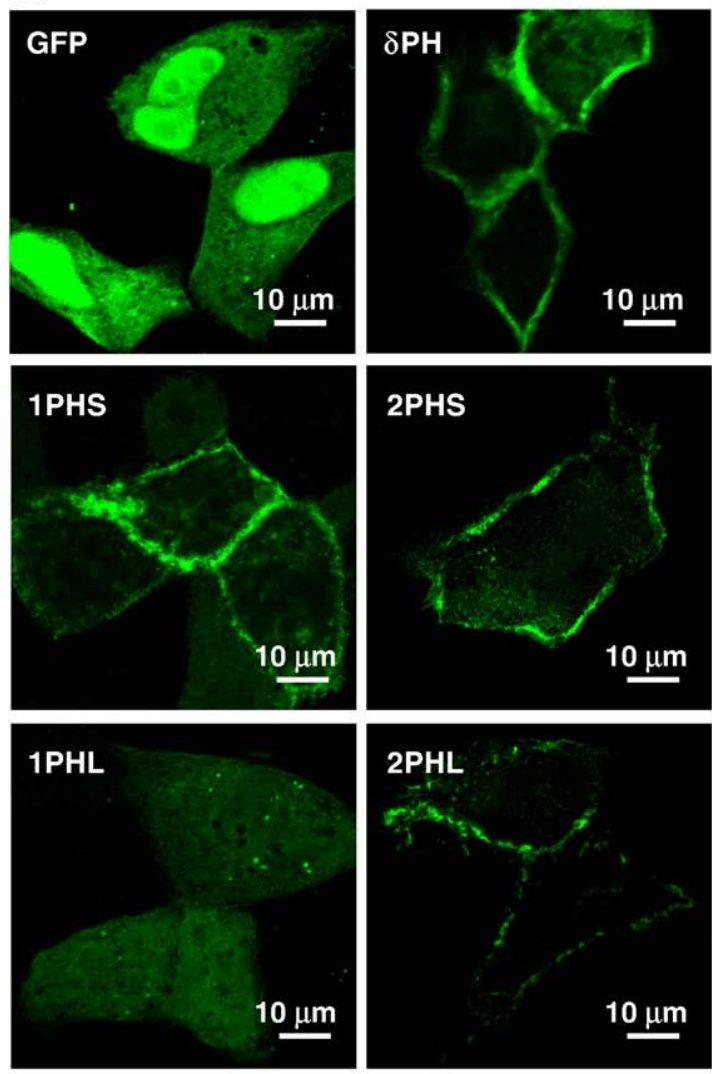

B

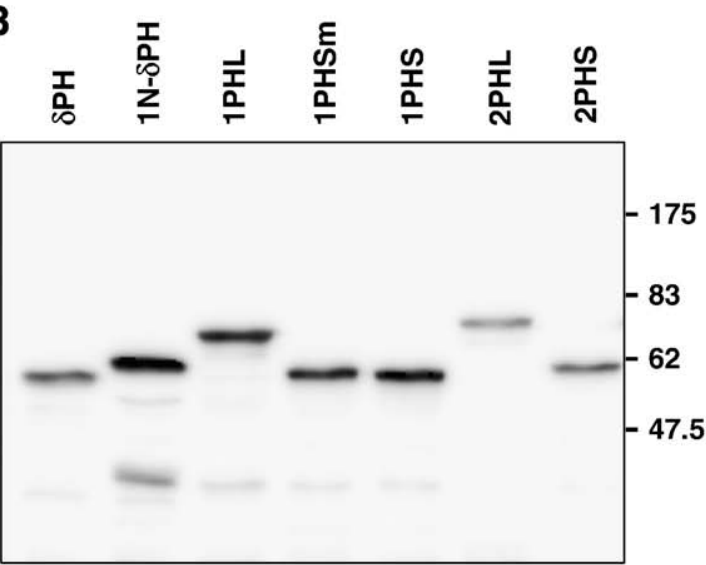

Fig. 3. Subcellular localisation of PH domains fused with GFP in MDCK cells. (A) MDCK cells grown on a glass coverslip were transiently transfected with each construct fused with GFP, followed by fixation with $4 \%$ paraformaldehyde. Images were obtained using a confocal laser scanning microscope (Zeiss: LSM510-Meta) and are typical images from more than 20 independent experiments. (B) GFP-fused PH domains expressed in MDCK cells were analysed for a lack of severe hydrolysis inside cells by Western blotting using anti-GFP antibody. 
A
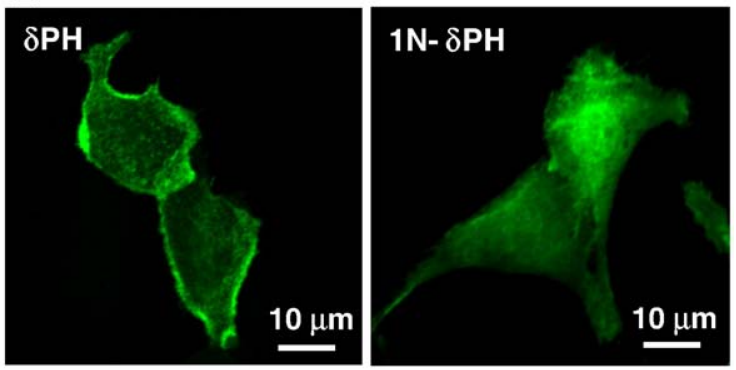

B

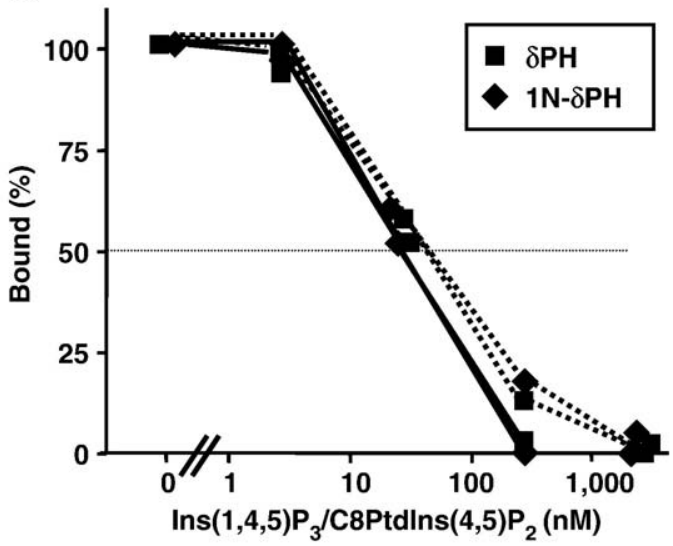

Fig. 4. Effect of the N-terminal extension of PRIP-1 on membrane localisation of PLC- $\delta 1$ $\mathrm{PH}$ domain. (A) Subcellular localisation of $\delta \mathrm{PH}$ and $1 \mathrm{~N}-\delta \mathrm{PH}$ expressed in MDCK cells. Pictures shown are typical of more than 20 images. (B) Displacement profiles by Ins $(1,4,5) \mathrm{P}_{3}$ (solid lines) and C8-PtdIns $(4,5) \mathrm{P}_{2}$ (dotted lines) of $\left[{ }^{3} \mathrm{H}\right] \operatorname{Ins}(1,4,5) \mathrm{P}_{3}$ bound to $\delta \mathrm{PH}$ or $1 \mathrm{~N}-\delta \mathrm{PH}$. For the purity of the protein samples used, see Fig. $1 \mathrm{~B}$. Thin dotted line indicates $50 \%$ displacement. Results are the mean of two independent experiments.

to be higher than the other PH domains ( $\mathrm{PH}$ domains from PRIP), since the binding profile to increasing concentrations of PtdIns $(4,5) \mathrm{P}_{2}$ in liposomes was steep in clear contrast to the shallow profiles observed with the other PH domains (Fig. 5B). It was noteworthy that $1 \mathrm{PHL}$ localised mainly inside cells was also capable of binding to liposomes containing PtdIns $(4,5) \mathrm{P}_{2}$, to a similar extent as $1 \mathrm{PHS}$ and 2PHL. Furthermore, 1PHSm induced decreased binding to liposomes containing an increasing concentration of PtdIns $(4,5) \mathrm{P}_{2}$, but still showing binding over non-specific binding levels (Fig. $5 \mathrm{~B}$ ). This can probably be attributed to electrostatic interactions between anionic phospholipids [PtdIns $(4,5) \mathrm{P}_{2}$ ] and basic amino acids (R131, R132 and K133) remaining in the mutant. These results probably indicate that the $\mathrm{PH}$ domains of PRIP-1 and -2 would directly associate with $\operatorname{PtdIns}(4,5) \mathrm{P}_{2}$ present in reconstituted lipid bilayers, and in the cellular surface membrane, such as $\delta \mathrm{PH}$, and further, together with those of Figs. 2 and 3 , indicate that the $\mathrm{N}$-terminal extension preceding the $\mathrm{PH}$ domain of PRIP-1, but not PRIP-2, provides some interference in the association under cellular conditions. When we compared the binding inhibition of 1PHS and 1PHL to liposomes containing $1.2 \mathrm{~mol} \%$ PtdIns $(4,5) \mathrm{P}_{2}$ (probably the concentration at even distribution, see below) by varying the concentration of Ins $(1,4,5) \mathrm{P}_{3}$, we observed that $1 \mathrm{PHL}$ was more sensitive to increasing concentrations of $\operatorname{Ins}(1,4,5) \mathrm{P}_{3}$ (Supplementary Fig. 1). This observation might partly explain the difference in cellular localisation, despite little difference in binding profiles of solutions and liposomes. PRIP-1 under cellular physiological conditions might be regulated in its membrane association by a subtle change in the concentration of $\operatorname{Ins}(1,4,5) \mathrm{P}_{3}$.

In the previous experiment [13], however, we observed a distinct difference between $\delta \mathrm{PH}$ and $1 \mathrm{PHS} ; \delta \mathrm{PH}$ found at the surface membrane was detached toward the cytosol in response to cellular stimulation, probably by decreasing $\operatorname{PtdIns}(4,5) \mathrm{P}_{2}$ concentration caused by hydrolysis, whereas 1 PHS remained present around the plasma membrane even upon cellular stimulation. We here again observed that 1PHS, 2PHS and 2PHL were hardly detached from the surface membrane of MDCK cells upon cellular stimulation with ATP, a purinergic agonist (data not shown). Ins $(1,4,5) \mathrm{P}_{3}$ production in HeLa cells stimulated with ATP was measured, with the result that the production of Ins $(1,4,5) \mathrm{P}_{3}$ was not inhibited by $1 \mathrm{PHS}$, but was inhibited in HeLa cells expressing $\delta \mathrm{PH}$, probably because PtdIns $(4,5)$ $\mathrm{P}_{2}$ complexed with the $\mathrm{PH}$ domain could not be a good substrate for hydrolysis [13]. From these results we had tentatively assumed the possibility that 1 PHS seen at the plasma membrane is only present just beneath the plasma membrane without direct binding to PtdIns $(4,5) \mathrm{P}_{2}$. However, this possibility might have to be amended, as the $\mathrm{PH}$ domain of PRIP-1 and -2 directly associates with PtdIns (4,5) $\mathrm{P}_{2}$ present in liposomes and the cell surface membrane, as shown in Figs. 3 and 5, although the affinity is apparently lower than that of $\delta \mathrm{PH}$, as seen in Fig. 5B. The concentration of $\operatorname{PtdIns}(4,5) \mathrm{P}_{2}$ has been estimated to be 30-160 $\mu \mathrm{M}$ depending on cell types under the assumption of even distribution [35-37] or $\sim 1 \mathrm{~mol} \%$ (in a different unit) for total plasma membrane of PC12 cells with asymmetrical leaflet distribution [3537], but that in the microdomain for dense-core vesicle docking, for instance, was estimated to be $\sim 6 \mathrm{~mol} \%$ equivalent up to $\sim 1 \mathrm{mM}$ [38]. Taken together, we might assume that the PH domains from PRIP-1 and -2 with lower affinity to $\operatorname{PtdIns}(4,5) \mathrm{P}_{2}$ bind to the surface membrane restricted to sites abundant with the lipid, while that from PLC- $\delta 1$ could bind PtdIns(4,5) $\mathrm{P}_{2}$ present anywhere in the surface membrane, which could be a good substrate for PLC, since the reported $\mathrm{Km}$ value is around $50-100 \mu \mathrm{M}[32,33]$.

\subsection{Membrane association of PH domain using permeabilised cells}

PC12 cells have been widely used for the exocytosis assay of densecore vesicles containing norepinephrine, the process of which requires
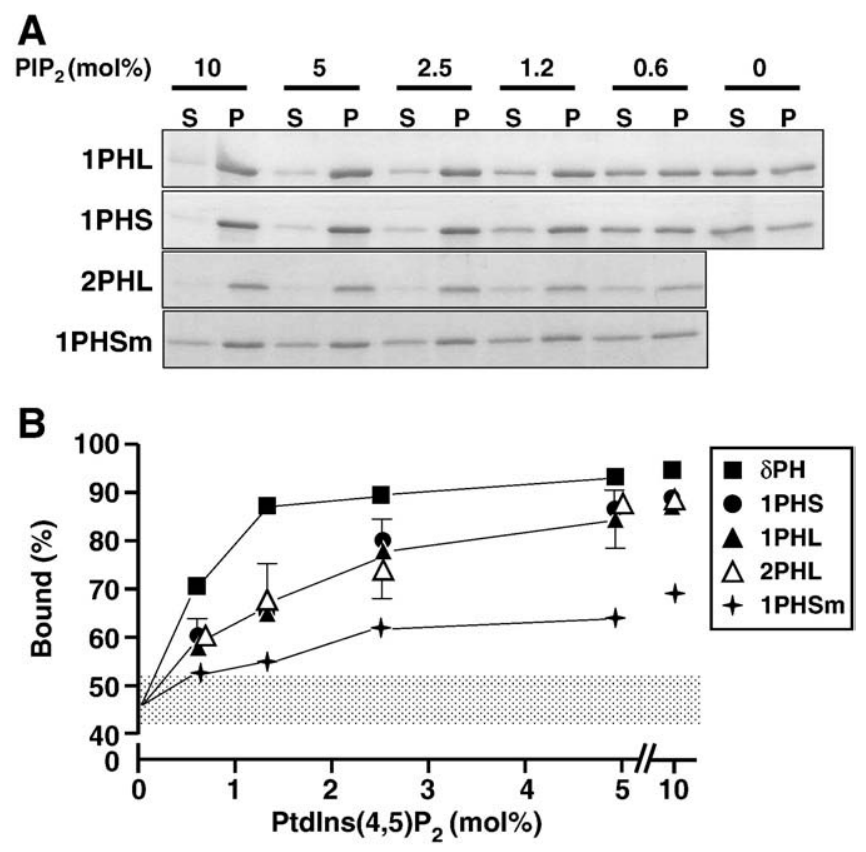

Fig. 5. Binding of $\mathrm{PH}$ domains to liposomes containing $\operatorname{PtdIns}(4,5) \mathrm{P}_{2}$. $\mathrm{PC}$ liposomes containing various concentrations of $\operatorname{PtdIns}(4,5) \mathrm{P}_{2}$ were used to bind $\mathrm{PH}$ domains, as described in Materials and methods. (A) Typical CBB staining pattern of the supernatant (S) and pellet $(\mathrm{P})$ at each PtdIns $(4,5) \mathrm{P}_{2}$ concentration. (B) Summary of five independent experiments. Results are represented as the mean \pm SE. Some error bars are behind symbols. Horizontal bar pattern indicates the non-specific binding range, i.e., the binding of protein samples to PC liposomes without PtdIns $(4,5) \mathrm{P}_{2}$. Each construct of the $\mathrm{PH}$ domains at a protein concentration of $50 \mathrm{nM}(2.5 \mathrm{pmol})$ was assayed. 
A
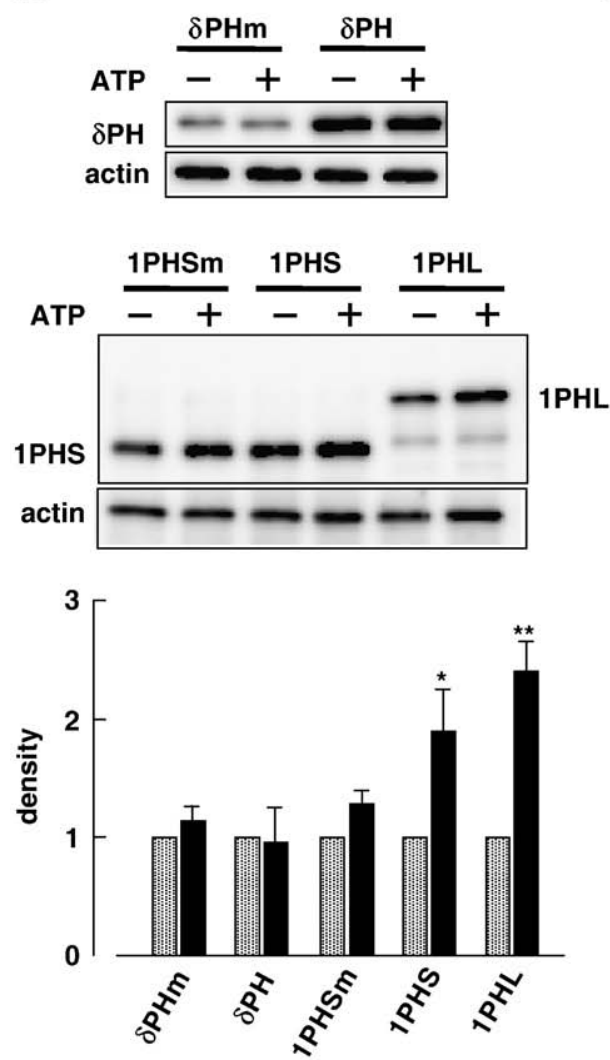

B
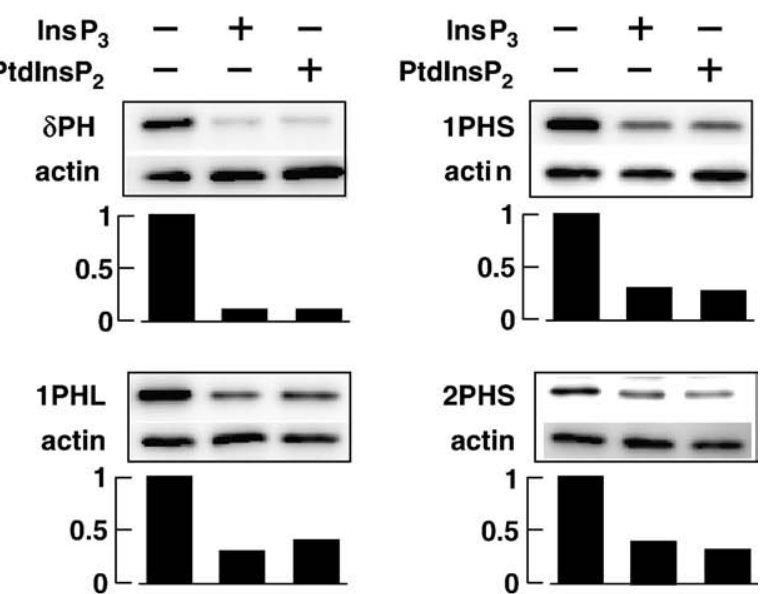

C

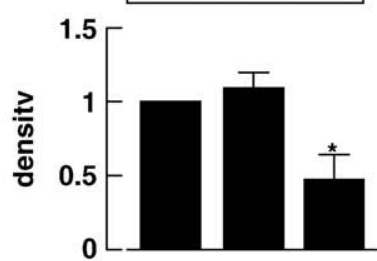

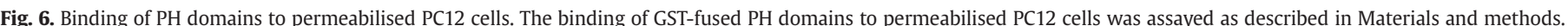

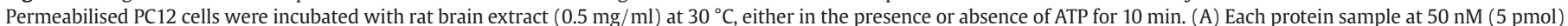

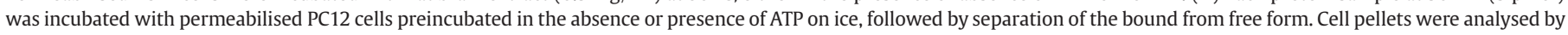

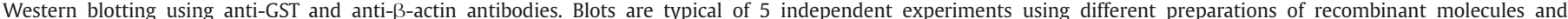

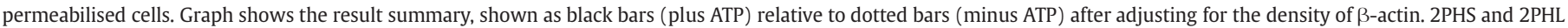

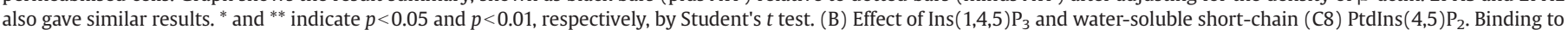

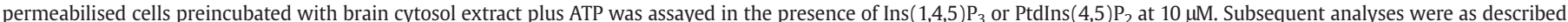

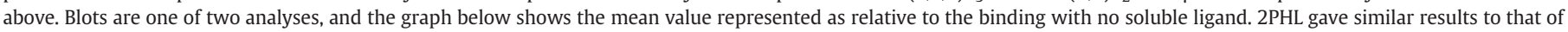

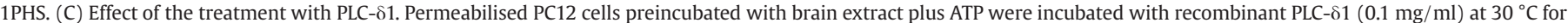

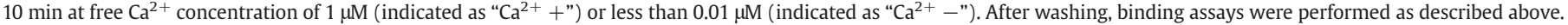
Blots are the typical of three independent experiments, and the graph shows the summary, represented as relative to the binding with no treatment. *; $p<0.05$.

the preceding synthesis of PtdIns $(4,5) \mathrm{P}_{2}$ to enable vesicles and plasma membranes to develop competence for $\mathrm{Ca}^{2+}$-triggered fusion [31,3943]. So here we employed PC12 cells permeabilised with saponin for analysis. Permeabilised cells were preincubated with the brain cytosol extract for $10 \mathrm{~min}$ at $30{ }^{\circ} \mathrm{C}$ in the presence of Mg-ATP, during which PtdIns $(4,5) \mathrm{P}_{2}$ were probably synthesised $[39,40]$, and then washed once briefly, followed by incubation with recombinant molecules of interest at $50 \mathrm{nM}$ for $10 \mathrm{~min}$ on ice, and separation by centrifugation and analysis of bound molecules by Western blotting. 1PHS and 1PHL bound to permeabilised cells like $\delta \mathrm{PH}$, and the amounts bound increased when cells were preincubated with Mg-ATP, as shown in Fig. 6A. Such an increase in binding was little observed with $\delta \mathrm{PH}$. Binding was inhibited by the presence of Ins $(1,4,5) \mathrm{P}_{3}$ and C8-PtdIns $(4,5) \mathrm{P}_{2}$ (Fig. 6B). Similar binding profiles were observed with the PH domain of PRIP-2 (Fig. 6B). Moreover, binding decreased when permeabilised cells were treated with recombinant PLC- $\delta 1$ in the presence of $\mathrm{Ca}^{2+}$ hydrolysing PtdIns $(4,5) \mathrm{P}_{2}$, but not in its absence (Fig. 6C). Bound $\delta \mathrm{PH}$ was reduced by incubating with 30-100-fold 1PHS, but not with mutant 1PHS (1PHSm) (results not shown), indicating that the PH domain of PRIP competes for PtdIns $(4,5) \mathrm{P}_{2}$ with $\delta \mathrm{PH}$. These results clearly indicated that the binding observed with the $\mathrm{PH}$ domain of PRIP is mediated through the association with PtdIns $(4,5) \mathrm{P}_{2}$ mainly synthesised during preincubation at the plasma membranes. $\delta \mathrm{PH}$ or $1 \mathrm{PHS}$ at various concentrations, including $50 \mathrm{nM}$ described above, were incubated with cells preincubated with brain extract in either the presence or absence of Mg-ATP (see Supplementary Fig. 2). Both $\delta \mathrm{PH}$ and $1 \mathrm{PHS}$ showed dose-dependent binding to saponinpermeabilised cells, which are attributed to those to $\operatorname{PtdIns}(4,5) \mathrm{P}_{2}$ remaining or newly synthesised in cells preincubated in the absence or presence of Mg-ATP, respectively. Preincubation with brain cytosol plus Mg-ATP did not cause a big change in $\delta P H$ binding at any concentration, while it caused a 2-3-fold increase in the binding of 1PHS (see Supplementary Fig. 2). 1PHL showed similar binding profile to the short version, but to a slightly lesser extent (data not shown). The results were consistent with the binding assay performed using liposomes containing various concentrations of $\operatorname{PtdIns}(4,5) \mathrm{P}_{2}$, shown in Fig. 5; the binding of $1 \mathrm{PHS}, 1 \mathrm{PHL}$ and $2 \mathrm{PHL}$ to liposomes containing $1.2 \mathrm{~mol} \%$ PtdIns $(4,5) \mathrm{P}_{2}$ increased 2-3-fold when PtdIns $(4,5) \mathrm{P}_{2}$ was increased to $5 \mathrm{~mol} \%$, while that of $\delta \mathrm{PH}$ increased a little. James et al. [38] recently reported that the amount of $\operatorname{PtdIns}(4,5) \mathrm{P}_{2}$ under unprimed conditions ( $\sim \mathrm{mol} \%$ ) increased to about $6 \mathrm{~mol} \%$ upon priming (i.e., incubation with brain extract plus ATP), thus indicating quantitative similarity of the results obtained with liposomes and permeabilised cells.

Finally, the effect of $\mathrm{Ca}^{2+}$ concentration on the association of the $\mathrm{PH}$ domain with the following EF hand motifs to permeabilised cells 
A
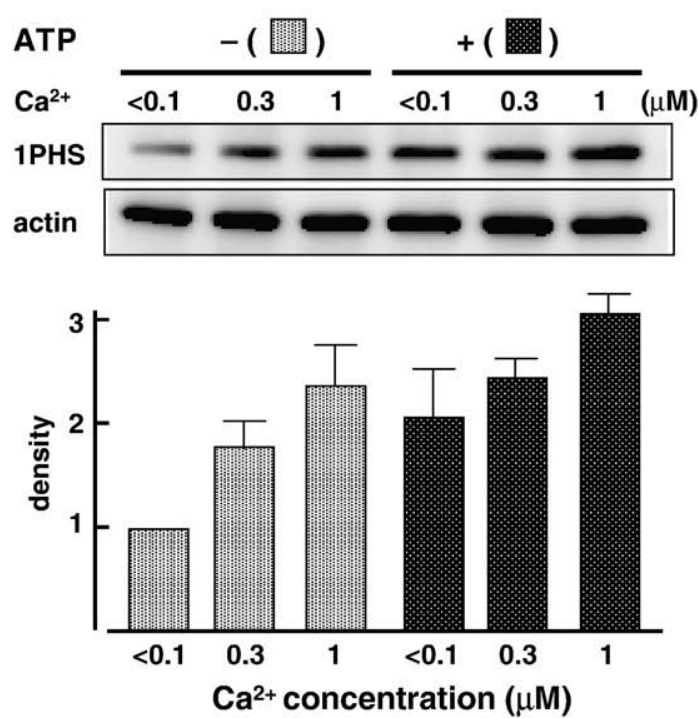

B
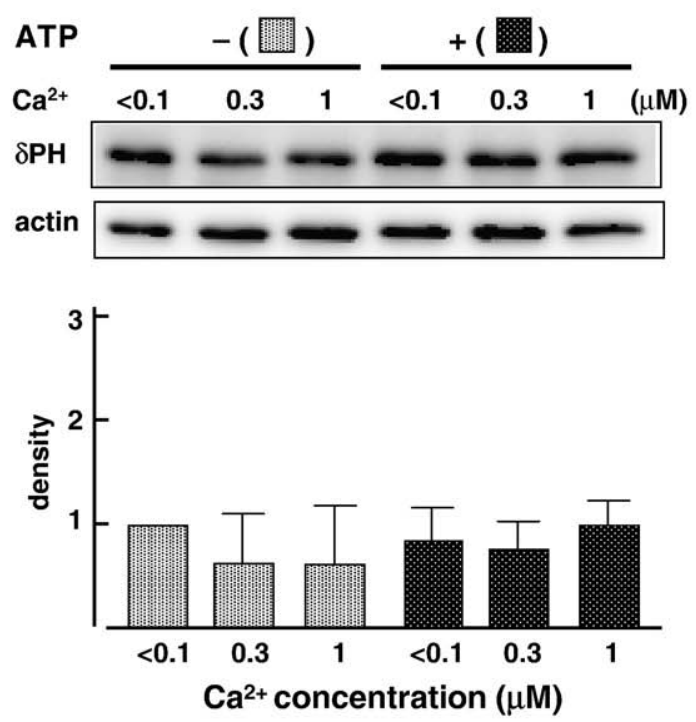

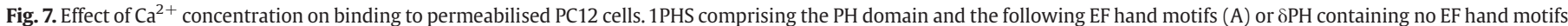

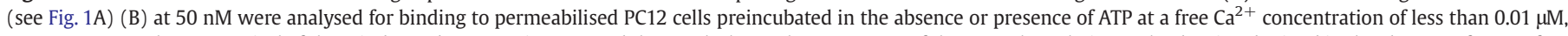

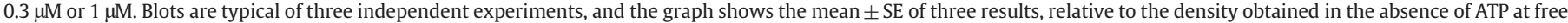
$\mathrm{Ca}^{2+}$ of less than $0.01 \mu \mathrm{M}$.

was examined. The constructs for PH domain prepared in this study contained EF hand motifs (see Fig. 1A and B); 1PHS was mainly used here. As shown in Fig. 7, the binding of the PH domain with EF hand motifs (1PHS) increased in a $\mathrm{Ca}^{2+}$-dependent manner, while $\delta \mathrm{PH}$ lacking the following EF hand motifs showed no $\mathrm{Ca}^{2+}$-dependent increase of binding, results similar to those observed using liposomes containing PtdIns $(4,5) \mathrm{P}_{2}[11]$. The impact of the $\mathrm{Ca}^{2+}$ effect appeared bigger under the unprimed conditions, but was still observed under primed conditions, indicating the physiological relevance of this $\mathrm{Ca}^{2+}$ effect.

\section{Acknowledgements}

This work was funded by Grants-in-Aid for Scientific Research from the Ministry of Education, Culture, Sports, Science and Technology of Japan (to HT, TK and MH), The Uehara Memorial Foundation (to $\mathrm{MH}$ ) and The Japan Diabetes Association (to TK). JG is a recipient of the Iwadare Scholarship and MF is a research fellow supported by the Japan Society for the Promotion of Science (JSPS).

\section{Appendix A. Supplementary data}

Supplementary data associated with this article can be found, in the online version, at doi:10.1016/j.cellsig.2009.03.008.

\section{References}

[1] T. Kanematsu, H. Takeya, Y. Watanabe, S. Ozaki, M. Yoshida, T. Koga, S. Iwanaga, M. Hirata, J. Biol. Chem. 267 (1992) 6518.

[2] T. Kanematsu, Y. Misumi, Y. Watanabe, S. Ozaki, T. Koga, S. Iwanaga, Y. Ikehara, M. Hirata, Biochem. J. 313 (1996) 319.

[3] T. Kanematsu, K. Yoshimura, K. Hidaka, H. Takeuchi, M. Katan, M. Hirata, Eur. J. Biochem. 267 (2000) 2731.

[4] L.O. Essen, O. Perisic, R. Cheung, M. Katan, R.L. Williams, Nature 380 (1996) 595-602.

[5] M. Yoshida, T. Kanematsu, Y. Watanabe, T. Koga, S. Ozaki, S. Iwanaga, M. Hirata, J. Biochem. 115 (1994) 973.

[6] H. Takeuchi, T. Kanematsu, Y. Misumi, H.B. Yaakob, H. Yagisawa, Y. Ikehara, Y. Watanabe, Z. Tan, S.B. Shears, M. Hirata, Biochem. J. 318 (1996) 561.

[7] H. Takeuchi, T. Kanematsu, Y. Misumi, F. Sakane, H. Konishi, U. Kikkawa, Y. Watanabe, M. Katan, M. Hirata, Biochim. Biophys. Acta 1359 (1997) 275.

[8] H. Takeuchi, M. Oike, H.F. Paterson, V. Allen, T. Kanematsu, Y. Ito, C. Erneux, M. Katan, M. Hirata, Biochem. J. 349 (2000) 357.
[9] K. Harada, H. Takeuchi, M. Oike, M. Matsuda, T. Kanematsu, H. Yagisawa, K.I. Nakayama, K. Maeda, C. Erneux, M. Hirata, J. Cell. Physiol. 202 (2005) 422.

[10] H. Takeuchi, T. Kanematsu, Y. Misumi, M. Hirata, Chem. Phys. Lipids. 98 (1999) 35.

[11] T. Yamamoto, H. Takeuchi, T. Kanematsu, V. Allen, H. Yagisawa, U. Kikkawa, Y. Watanabe, A. Nakasima, M. Katan, M. Hirata, Eur. J. Biochem. 265 (1999) 481.

[12] V. Allen, P. Swigart, R. Cheung, S. Cockcroft, M. Katan, Biochem. J. 327 (1997) 545

[13] N. Matsuki, H. Takeuchi, M. Oike, J.X. Liao, S. Ferry, M. Ohishi, T. Kanematsu, M. Hirata, Curr. Top. Biochem. Res. 4 (2001) 117

[14] M. Otsuki, K. Fukami, T. Kohno, J. Yokota, T. Takenawa, Biochem. Biophys. Res. Commun. 266 (1999) 97.

[15] M. Matsuda, T. Kanematsu, H. Takeuchi, T. Kukita, M. Hirata, Neurosci. Lett. 257 (1998) 97.

[16] T.F. Martin, Annu. Rev, Cell. Dev, Biol. 14 (1998) 231.

[17] T.F. Martin, K.M. Loyet, V.A. Barry, J.A. Kowalchyk, Biochem. Soc. Trans. 25 (1997) 1137.

[18] T.F. Martin, Curr. Opin. Cell. Bio. 13 (2001) 493.

[19] O. Cremona, P. De Camilli, J. Cell. Sci. 114 (2001) 1041.

[20] E.J. Ungewichell, L. Hinrichsen, Curr. Opin. Cell Biol. 19 (2007) 417.

[21] D.W. Hilgemann, S. Feng, C. Nasuhoglu, Sci. STKE (111) (2001) RE19.

[22] M. McDermott, M.J. Wakelam, A.J. Morris, Biochem. Cell. Biol. 82 (2004) 225

[23] M.A. Lemmon, Traffic 4 (2003) 201.

[24] P.A. Janmey, U. Lindberg, Nat. Rev. Mol. Cell. Biol. 5 (2004) 658.

[25] T. Balla, J. Cell. Sci. 118 (2005) 2093.

[26] T. Takenawa, T. Itoh, IUBMB Life 58 (2006) 296.

[27] H. Yagisawa, M. Hirata, T. Kanematsu, Y. Watanabe, S. Ozaki, K. Sakuma, H. Tanaka N. Yabuta, H. Kamata, H. Hirata, et al., J. Biol. Chem. 269 (1994) 20179.

[28] P. Varnai, T. Balla, J. Cell Biol. 143 (1998) 501.

[29] H. Takeuchi, M. Matsuda, T. Yamamoto, T. Kanematsu, U. Kikkawa, H. Yagisawa, Y. Watanabe, M. Hirata, Biochem. J. 334 (1998) 211.

[30] R.N. Grishanin, J.A. Kowalchyk, V.A. Klenchin, K. Ann, C.A. Earles, E.R. Chapman, R.R. Gerona, T.F. Martin, Neuron 43 (2004) 551.

[31] V.A. Klenchin, J.A. Kowalchyk, T.F. Martin, Methods 16 (1998) 204.

[32] P. Garcia, R. Gupta, S. Shah, A.J. Morris, S.A. Rudge, S. Scarlata, V. Petrova, S. McLaughlin, M.J. Rebecchi, Biochemistry 34 (1995) 16228.

[33] M.A. Lemmon, K.M. Ferguson, R. O'Brien, P.B. Sigler, J. Schlessinger, Proc. Natl. Acad. Sci. USA 92 (1995) 10472.

[34] H. Yagisawa, K. Sakuma, H.F. Paterson, R. Cheung, V. Allen, H. Hirata, Y. Watanabe, M. Hirata, R.L. Williams, M. Katan, J. Biol. Chem. 273 (1998) 417.

[35] J.E. Ferrell, W.H. Huestis, J. Cell. Biol. 98 (1984) 1992

[36] C. Hagelberg, D. Allan, Biochem. J. 271 (1990) 831.

[37] D. Tran, P. Gascard, B. Berthon, K. Fukami, T. Takenawa, F. Giraud, M. Claret, Cell Signal. 5 (1993) 565.

[38] D.J. James, C. Khodthong, J.A. Kowalchyk, T.F. Martin, J. Cell. Biol. 182 (2008) 355.

[39] J.C. Hay, P.L. Fisette, G.H. Jenkins, K. Fukami, T. Takenawa, R.A. Anderson, T.F. Martin, Nature 374 (1995) 173.

[40] J.C. Hay, T.F. Martin, J. Cell. Biol. 119 (1992) 139.

[41] R.W. Holz, M.D. Hlubek, S.D. Sorensen, S.K. Fisher, T. Balla, S. Ozaki, G.D. Prestwich, E.L. Stuenkel, M.A. Bittner, J. Biol. Chem. 275 (2000) 17878.

[42] Y.A. Chen, S.J. Scales, V. Duvvuri, M. Murthy, S.M. Patel, H. Schulman, R.H. Scheller J. Biol. Chem. 276 (2001) 26680.

[43] H.L. Olsen, M. Hoy, W. Zhang, A.M. Bertorello, K. Bokvist, K. Capito, A.M. Efanov, B. Meister, P. Thams, S.N. Yang, et al., Proc. Natl. Acad. Sci. USA 100 (2003) 5187. 


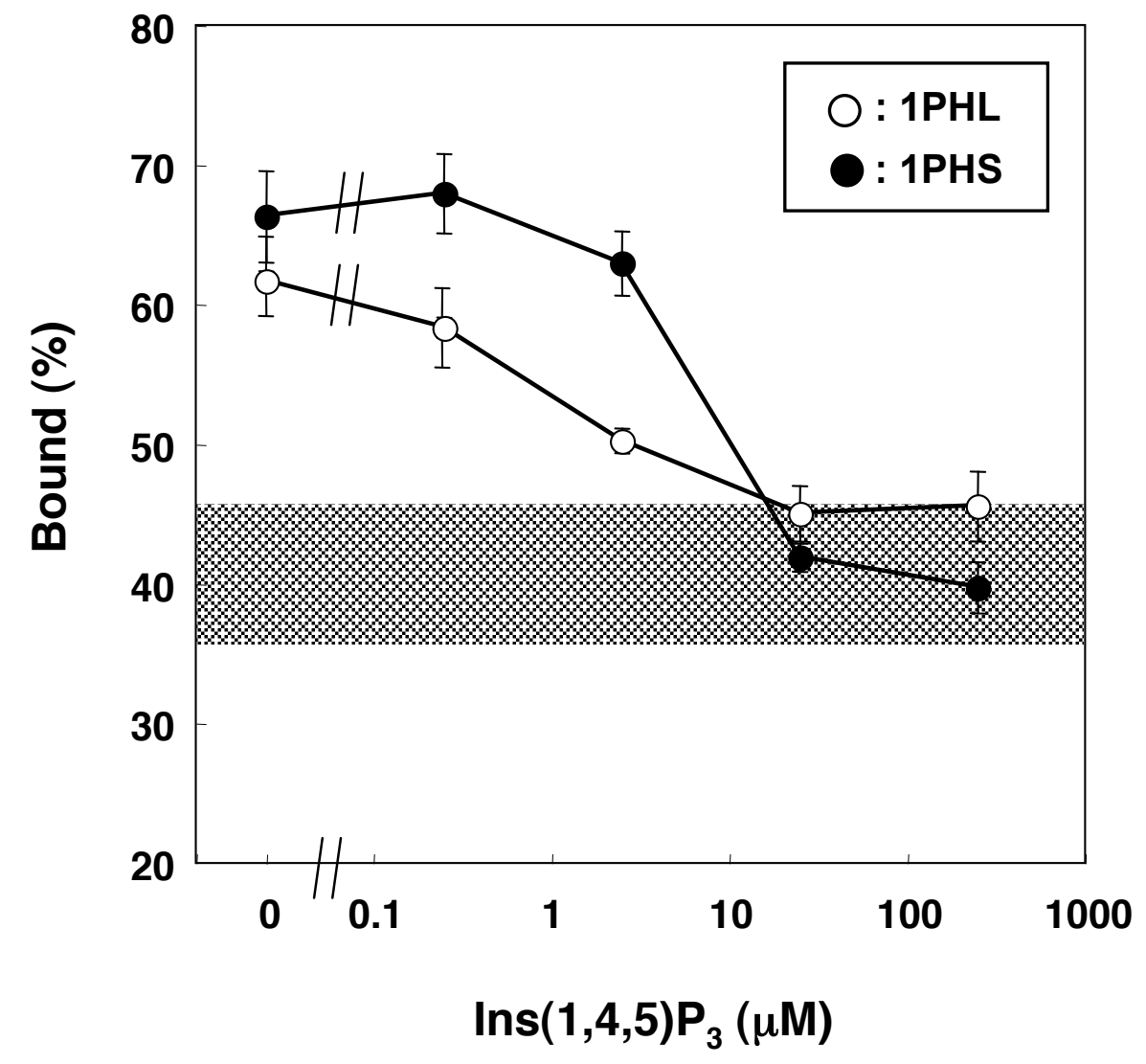

Supplementary Figure 1. Gao et al 
A
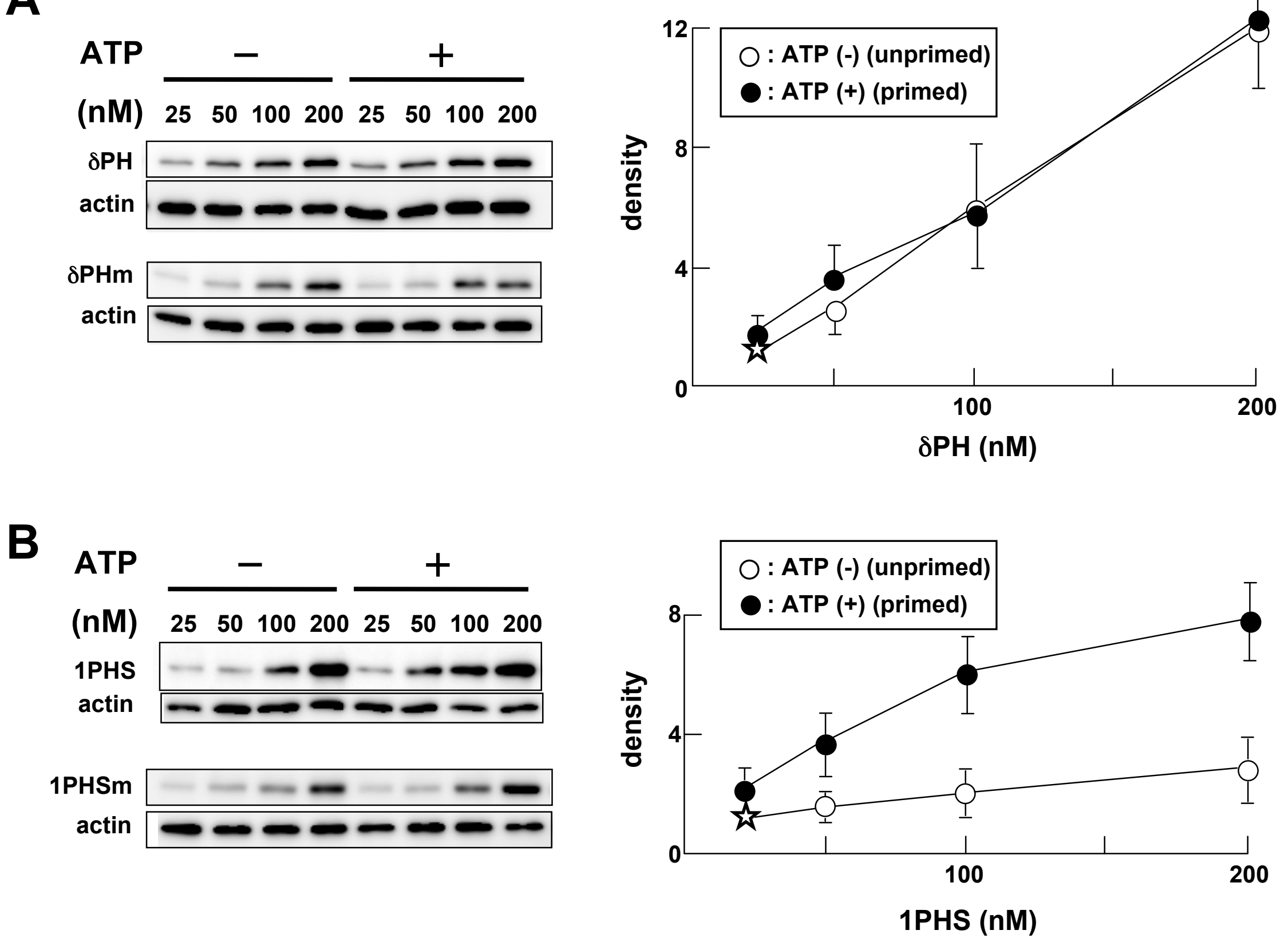

Supplementary Figure 2. Gao et al 